\title{
Influence of Regions Innovative and Investment Activity on Their Social-Economic Development: Results of an Empirical Study
}

\author{
Prof. Nataliya A. Tyuleneva \\ National Research Tomsk State University, Russia \\ aola79@yandex.ru \\ Anastasia A. Lisnyak \\ National Research Tomsk State University, Russia \\ A2Lis@mail.ru
}

Doi:10.5901/mjss.2015.v6n3p347

\section{Abstract}

In this paper, the authors analyze methodological approaches to evaluation of innovative and investment activity and socialeconomic development of regions as well as subsequent methods to measure mutual influence of the factors. The obtained results allowed the authors to point out factors which influence regions' innovative and investment activity. The study discusses the experience of regional strategies' implementation through the example of the most innovatively active regions. The authors have carried out an empirical research related to creation of innovative territorial clusters. The methodology of mutual influences evaluation worked out during this study can be used to introduce changes into budget strategy and programs of regional innovative development and to evaluate how efficient is the implementation of cluster-based development programs.

Keywords: Russia, regional economics, evaluation methodology, innovative activity, investment activity, financing, innovative territorial cluster

\section{Introduction}

During the last decade, the global scientific community has been paying much attention to an innovative way of economic development. Leading economists and experts agree that innovative way of development can result with an increase in territorial competitive ability and economic growth.

The European Union has gained a specific experience in observation of innovative activity. The CIS concept is used in annual reports called European Innovation Scoreboard. It is also a basis for the EU's scientific research connected with innovations.

Nowadays the Russian system of innovation statistics has two directions of development. The first direction is a harmonization of the methodology with advanced international experience while the second is an improvement of those lines of research which have no equivalent in international practices.

In this respect, the methodological issues of evaluation of regions' innovative activity and national innovative system have become crucial recently. Literature review has shown that there is no any common approach to the scoring system for such an evaluation, and to the rules which describe the procedure of data collection and processing. Such aspects make innovation monitoring process more complicated for the European counties and Russia.

In our opinion, in order to work out recommendations for the increase of regional innovative activity, it is reasonable to compare and analyze interconnections between investment activity and innovative activity of regions. As a rule, an efficient implementation of innovations is connected with the need of investment, and thus the dependence of innovative activity on investment processes is explained. The specificities of such interconnections characterize "economic health" of a region to a certain extent.

\subsection{Research Objective}

The objectives of the present study are the following:

- to define factors which influence innovative activity and determine investment attractiveness of the Russian 
regions;

- to discuss examples of the most successful implementation of the innovative development strategies of the Russian regions;

- to find connections between regions' innovative and investment activity and their social-economic development.

\section{Literature Review}

A lot of modern scientific works are dedicated to problems of regional innovative and investment activity. For instance, R. Antonietti (2015) studies influence of greenfield FDI on the level of innovative activity of host territories. D. Hart (2001) examines the role of innovations in the increase and maintenance of territorial competitive ability. In this respect, the author points out paradoxical features of that process: as in companies, in an effort to raise their innovative activity, subject themselves to great risks and bring into question further operation and competitive ability.

A great number of research gives attention to an effect of FDI on social and economic state of host regions (Lipsey et al., 2004, Driffield et al., 2013). S. Menghinello (2010) compares the influence of production agglomerations and FDI on the regional development, studying what outcome these two phenomena have when occurring simultaneously. $\mathrm{N}$. Driffield (2010) in his work emphasizes an important role of foreign investments and knowledge migration in regional productivity enhancement. J. Jones (2008) discusses consequences of FDI for the economic development of the regions with high share of businesses with foreign ownership. In the study mentioned the attraction of foreign investment is considered as a part of regional strategies.

Many authors point out a strong connection between investment activity and advancement of regional cluster structures. M. Giblin (2008) studies how FDI and regional cluster-based development are connected, considering government as a key element in the discussed process. N. Phelps (2008) highlights controversial results obtained through attempts of the government to create "artificial" production agglomerations though the attraction of FDI into regions.

What concerns connection of foreign investments and innovative development of the Russian regions is that investment does not have a great effect on innovative development according to the results of our research of the Siberian Federal District regions. Share of foreign investment in total financial sources of innovative companies accounts for $0,1-0,4 \%$ and during the last years there has not been any data on this indicator in statistical digests at all. Foreign investments, including those from the EU, can be found basically in the regions with advanced base materials sector such as Kemerovo Region, Irkutsk Region, Tomsk Region, Krasnoyarsk Krai (Tyuleneva, 2013 - Peoples' Friendship University of Russia).

In terms of what has been said above, the most efficient and promising model nowadays is a so called improved R\&D model developed by A. Akaev (2014) for the purposes of forecast analysis of economic growth's total productivity factors. Along with a number of workers engaged in R\&D the model considers expenditures per 1 worker engaged in R\&D and a personnel qualification. However, the model only regards a national innovative system and doesn't involve regional level studies.

\section{Methodology}

Having studied the most successful international practices in the field of counties' and regions' innovative activity evaluation we have worked out a methodology for identification and evaluation of connections between innovative and investment activity and social-economic development of regions. Our methodology includes three correspondent groups of indicators. We have made calculations according to the methodology based on two groups of indicators where the first group characterizes resources of innovative activity and the second group describes the results of such activity.

As a part of the study, we have carried out a comparative analysis of the Russian regions on the basis of statistical data over the period of 2011-2013. The study also involves rating scale analysis of the most innovatively active regions, ranking according to the final values of the indicators shown by the regions. There is also an interpretation of regional innovative and investment activity rankings published by the Russian organizations. To identify connections between indicators we have conducted correlation analysis and done statistical evaluation of significance. 


\section{Specific Features of the Innovative and Investment Activity and Social-Economic Development of the Russian Regions}

\subsection{Innovative Territorial Clusters and Their Role in Transition to Innovative Development}

A background for the development of cluster-based programs in the Russian regions and a comparative analysis of the innovatively active Russian regions (evidence from the Siberian Federal District) with the use of a cluster analysis methods are described in our previous works (Tyuleneva, 2013 - ERIEP).

Innovative development of the Russian economy characterized by the leading role of knowledge and hi-tech industries is only possible under conditions of economical diversification, increase of enterprises' innovative activity on the basis of new forms of business and government interaction. In The Concept of long-term social and economic development of the Russian Federation until 2020 (Ministry of Economic Development of the Russian Federation, 2008), a stimulation of activity of emerging territorial-production clusters is presented as one of the key guidelines. The concept of a cluster-based regional economy management allows to identify the factors of regional competitiveness and helps develop priority sectors which determine investment attractiveness of the territories.

In 2012 the work group for private and state partnership development in the innovation field under the Governmental committee for hi-tech and innovation has made a List of twenty five innovative territorial clusters (ITC) according to the results of a competitive selection (Ministry of Economic Development of the Russian Federation, 2012). The List comprises two groups of clusters. The first group involves clusters which will be receiving federal budget subsidies during a five year period whilst clusters in the second group will not receive subsidies from the federal budget. Table 1 shows the federal districts where these clusters are located and the number the clusters mentioned.

Table 1: Innovative Territorial Clusters by Federal Districts

\begin{tabular}{|c|c|c|c|}
\hline Federal District & $\begin{array}{c}\text { Number of clusters which took part in } \\
\text { the selection }\end{array}$ & $\begin{array}{l}\text { Number of clusters which were } \\
\text { included in The List }\end{array}$ & $\begin{array}{l}\text { Share of clusters which received the } \\
\text { ITC status, } \%\end{array}$ \\
\hline \multicolumn{4}{|c|}{ European Russia } \\
\hline Central & 26 & 6 & 23 \\
\hline Northwestern & 11 & 3 (5 not including merged clusters) & 45 (not including merged clusters) \\
\hline Southern & 8 & - & - \\
\hline Volga & 22 & 9 & 41 \\
\hline $\begin{array}{c}\text { North } \\
\text { Caucasian }\end{array}$ & 1 & - & - \\
\hline \multicolumn{4}{|c|}{ Asian Russia } \\
\hline Ural & 6 & 1 & 17 \\
\hline Siberian & 18 & 5 (7 not including merged clusters) & 39 (not including merged clusters) \\
\hline Far Eastern & 2 & 1 & 50 \\
\hline
\end{tabular}

Source: Russian Cluster Observatory (2013 - Pilot Innovative Territorial Clusters in the Russian Federation)

As table 1 shows, most of the applications were submitted by the Central, Volga and Siberian federal districts. At the same time these districts lead in number of the clusters that gained the ITC status.

After the selection of pilot clusters in 2013 , there has been a start of a new selecting procedure for the financial support of particular events from the development programs of ITC (Russian Cluster Observatory, 2013 - Territorial Clusters. News Digest). It is interesting to note that the Russian subjects claimed more than 1,9 bln. rub. as financial support of cluster projects and that exceeded the amount of subsidies (1,3 bln. rub.) set in the federal budget of 2013. Such a big difference in sums can be explained by the various approaches used by regional authorities when claiming financial support and by the different level of preparation of the projects.

Among the most popular requests in the applicationsmwere financing of the development of innovative and educational infrastructure, support of the cluster organizations' operation, professional retraining and internships of the workers. According to the Government Executive Order 2,5 bln. rub. should have been given as a financial support of development programs of ITC in 2014 (Government of the Russian Federation, 2014). The results of these measures and the application efficiency of appropriated funds will be announced in 2016 after the analysis of reports by authorized bodies. 
The selection has shown that the regions with a relatively developed innovative system gain leading positions in the use of new forms of innovation support. This statement is confirmed by the fact that 19 out of 25 innovative territorial clusters are located in the regions which head the list of the regional innovative development rankings.

\subsection{AIRR Member Regions}

We note that regions' innovative activity has an uneven distribution. Up until recent times regional authorities have not been taking an active part in the development of innovative processes at their territories. However, today many Russian federal subjects have established legislation on innovations and innovative activity, where they also reveal the mechanisms of innovative activity support at regional level.

Many of the highest indicators of innovative activity have been shown by the AIRR (Association of Innovative Regions of Russia) member regions. The Association was created in 2010 and today it has 14 member regions from 85 Russian federal subjects. The purpose of the Association is to stimulate experience exchange in order to create a positive legal, economic and social environment for innovative development, as well as to organize and promote joint innovative, economic, science-and-technological and educational projects amongst the members of the Association and authorities.

In 2014 the Association published a Ranking of the Russian regions' innovative development which comprised 23 indicators of innovative activity, including R\&D and social and economic conditions, and analysis of 83 regions of the Russian Federation (Association of Innovative Regions of Russia, 2014). According to the results they formed 5 groups of investors: strong, medium-strong, medium, medium-weak and weak. Table 2 shows the positions of the AIRR member regions in the overall ranking of regions' innovative development.

Table 2: Ranking of the AIRR member regions' innovative development

\begin{tabular}{|c|c|c|}
\hline Regions & Position in Overall Rating & Group \\
\hline Republic of Tatarstan & 3 & \multirow{5}{*}{ Strong Investors } \\
\hline Kaluga Region & 5 & \\
\hline Tomsk Region & 8 & \\
\hline Perm Krai & 10 & \\
\hline Novosibirsk Region & 11 & \\
\hline Ulyanovsk Region & 13 & \multirow{5}{*}{ Medium-Strong Investors } \\
\hline Samara Region & 15 & \\
\hline Republic of Bashkortostan & 16 & \\
\hline Krasnoyarsk Krai & 18 & \\
\hline Republic of Mordovia & 21 & \\
\hline Irkutsk Region & 30 & \multirow{4}{*}{ Medium Investors } \\
\hline Lipetsk Region & 34 & \\
\hline Tyumen Region & 39 & \\
\hline Altai Krai & 54 & \\
\hline
\end{tabular}

Source: Association of Innovative Regions of Russia, 2014

The ranking demonstrates high positions of the AIRR regions in comparison with other Russian regions. All the regions discussed belong to groups of strong, medium-strong and medium investors.

AIRR member regions actively conduct work towards fundraising. In order to attract investors, regions resort to different tools and activities including organization of different forums and investment platforms.

The regions also work out cluster-based development programs. For example, one of the key directions of production modernization proposed in the Strategy of Social and Economic Development of Novosibirsk Region is a transition to cluster programs. It is emphasized that the top priorities of the long-term development of Novosibirsk region will be implemented by means of a set of policies initiated by the authorities. This set will include innovative, social, production, cluster and investment policies. The authorities plan to implement effective economic and financial measures aimed at supporting the real sector of economy and the most competitive clusters. The work towards building a Cluster campus is conducted under the terms of the Concept of Cluster Policy of Novosibirsk Region.

Altai Krai has also set a course for cluster development. According to the Program of Social and Economic Development of Altai Krai until 2017 production policy of the region is aimed at the growth of industrial products' competitive ability in the national and international market. This is planned to create and develop competitive industrial 
clusters, a zone of advanced economic growth which will result in a structure diversification.

Among the middle-term goals set in the Development Strategy of Tomsk Region there is a formation of innovative and completive economy. To reach this goal, the government has worked out three main tasks: to create favorable investment climate and contribute to economical internalization; to contribute to growth of competitive ability and innovative activity of organizations; to contribute to development of high-tech production and clusters. The third task comprises creation of ten new high-tech clusters and more than 135 thousand high-performance workplaces.

Cluster policies implemented in all regions generally share the orientation to high level of employment maintenance, job creation, new types of products development, extension of small businesses' opportunities and increase of regional budget revenues.

One of the most reliable rankings of the Russian regions' investment attractiveness is an annual ranking publishing by the "Expert RA" rating agency (Table 3). So far they have issued the reports over a period of 1996-2014. Rankings of the Russian regions' investment attractiveness are based on the official information provided by the Federal Service for National Statistics, also known as Rosstat (Expert RA Rating Agency, 2014).

Table 3: AIRR regions: innovative territorial clusters and regional investment attractiveness ranking

\begin{tabular}{|c|c|c|}
\hline Region & Name of an Innovative Territorial Cluster & $\begin{array}{c}\text { Region' Investment Attractiveness } \\
\text { Ranking }\end{array}$ \\
\hline Kaluga Region & Pharmacy, biotechnology and biomedicine cluster (Obninsk city) & $\begin{array}{l}1 \mathrm{~A} \text { Maximum potential - minimum } \\
\text { risk }\end{array}$ \\
\hline Perm Krai & $\begin{array}{c}\text { Rocket engine building innovative territorial cluster: "Technopolis "New } \\
\text { Stellar" }\end{array}$ & 2B Medium potential - medium risk \\
\hline $\begin{array}{c}\text { Republic of } \\
\text { Bashkortostan }\end{array}$ & Petrochemical territorial cluster & $\begin{array}{l}\text { 2B Medium potential - } \\
\text { minimum risk }\end{array}$ \\
\hline Republic of Mordovia & $\begin{array}{c}\text { Energy- efficient lightning technology and intellectual systems of } \\
\text { lightning management }\end{array}$ & \begin{tabular}{|c|} 
3B2 Minimum potential - medium \\
risk
\end{tabular} \\
\hline Republic of Tatarstan & Kamsky innovative territorial and production cluster & $\begin{array}{l}\text { 1A Maximum potential - } \\
\text { minimum risk }\end{array}$ \\
\hline Samara Region & Innovative territorial aerospace cluster & $\begin{array}{l}\text { 2B Medium potential - minimum } \\
\text { risk }\end{array}$ \\
\hline Ulyanovsk Region & $\begin{array}{l}\text { Nuclear innovative cluster } \\
\text { (Dimitrovgrad city) }\end{array}$ & $\begin{array}{l}\text { 3B1 Minimum potential } \\
\text { - medium risk }\end{array}$ \\
\hline Altai Krai & Altai biopharmacy cluster & $\begin{array}{l}\text { 3B1 Minimum potential - medium } \\
\text { risk }\end{array}$ \\
\hline Kemerovo Region & Integrated coal and technology-related waste conversion. & $\begin{array}{l}\text { 2B Medium potential - minimum } \\
\text { risk }\end{array}$ \\
\hline Krasnoyarsk Krai & $\begin{array}{l}\text { Innovation technology cluster } \\
\text { (Zheleznogorsk city). }\end{array}$ & $\begin{array}{l}\text { 2B Medium potential - minimum } \\
\text { risk }\end{array}$ \\
\hline Novosibirsk Region & $\begin{array}{c}\text { United application: } \\
\text { Innovative territorial cluster in the field of information and } \\
\text { telecommunication technologies. } \\
\text { Biopharmacy cluster. }\end{array}$ & $\begin{array}{l}\text { 2B Medium potential - minimum } \\
\text { risk }\end{array}$ \\
\hline Tomsk Region & $\begin{array}{l}\text { United application: } \\
\text { Pharmacy and medical equipment. } \\
\text { IT and electronics. }\end{array}$ & $\begin{array}{l}\text { 3B1 Minimum potential - medium } \\
\text { risk }\end{array}$ \\
\hline
\end{tabular}

Source: Expert RA Rating Agency, 2014

There are two indicators in the ranking which help estimate investment attractiveness of a region: investment potential and investment risk. The potential shows what share a region has in the Russian market while risk is used to identify the scale of the problems occurring in a region. The total potential consists of 9 individual potentials: labor, financial, production, consumer, institutional, infrastructural, natural-resources, tourism and innovation potentials. The aggregated risk comprises 6 components: financial, social, managerial, economic, ecological and criminal risk. Contribution of every particular risk or potential to a total value is estimated on the basis of a questionnaire survey which involves representatives of expert, investment and banking communities.

Thus, the AIRR member regions are active developers of cluster policy and participants of the selection for pilot 
cluster support. These regions are characterized by the integration of educational and science-and-technological potential and industrial sector with state support. Moreover, many of the regions where the pilot innovative clusters are located have a high level of investment attractiveness. Taking into consideration the results of the research we can assume that the presence of innovative clusters in a region is an important factor of its investment attractiveness. At the same time, a development of sustainable investment programs for the pilot innovative clusters along with constant monitoring and control of their implementation will lead to increase of investment attractiveness of the majority of the regions working out projects of innovative territorial clusters.

\section{Data Analysis and Results of an Empirical Study}

The AIRR member regions discussed above have been chosen as a study object in the present research. We have also included Kemerovo region (Siberian Federal District) in the research, the region which gains leading position in a base materials sector and actively works out cluster development programs.

At the first stage of our research we have used the methodology that analyses how regional innovative and investment activity and social-economic development are connected. As it was mentioned above, we have worked out three groups of indicators presented in Table 4.

Table 4: Indicators for a comparative analysis of innovative and investment activity and social and economic development of regions

\begin{tabular}{|c|c|c|c|}
\hline $\begin{array}{c}\text { Number of } \\
\text { indicator }\end{array}$ & Innovative activity & Investment activity & $\begin{array}{c}\text { Social and economic } \\
\text { development }\end{array}$ \\
\hline 1 & $\begin{array}{c}\text { Volume of innovatory production, works, } \\
\text { services, mln. RUR }\end{array}$ & Fixed capital investments, mln. RUR & $\begin{array}{c}\text { Gross regional product } \\
\text { per capita, RUR }\end{array}$ \\
\hline 2 & $\begin{array}{c}\text { Expenses of organizations on technological } \\
\text { innovations, mln. RUR }\end{array}$ & $\begin{array}{c}\text { Fixed capital investments per capita (at } \\
\text { actual prices), RUR }\end{array}$ & $\begin{array}{c}\text { Average per capita money } \\
\text { income (monthly), RUR }\end{array}$ \\
\hline 3 & $\begin{array}{c}\text { Trade of technologies with foreign countries by } \\
\text { fields of agreements, mln. dol. }\end{array}$ & $\begin{array}{c}\text { Fixed assets depreciation rate (end of } \\
\text { the year), } \%\end{array}$ & $\begin{array}{c}\text { Average annual level of } \\
\text { unemployed, } \%\end{array}$ \\
\hline 5 & $\begin{array}{c}\text { Number of issued patents on inventions and } \\
\text { useful models, unit }\end{array}$ & $\begin{array}{c}\text { Share of loss-making organizations } \\
\text { (percentage of total number of } \\
\text { organizations) }\end{array}$ & $\begin{array}{c}\text { Retail trade turnover per } \\
\text { capita, RUR }\end{array}$ \\
\hline 6 & $\begin{array}{c}\text { Innovative activity of organizations (Share of } \\
\text { organizations implementing innovations in total } \\
\text { number of organizations), } \%\end{array}$ & $\begin{array}{c}\text { Accumulated foreign direct investments, } \\
\text { mln.dol. }\end{array}$ & $\begin{array}{c}\text { Graduates of higher } \\
\text { educational institutions, } \\
\text { thou. persons }\end{array}$ \\
\hline
\end{tabular}

Source: Made up by the authors

The next step is to define the place of each region among the other regions taken into consideration according to their level of innovative and investment activity and social and economic development over the period of 2011-2013. The lowest total value means the best position of the region in comparison with the others. The results are presented in the Table 5.

Table 5: Ranking of regions according to their level of innovative and investment activity and social and economic development

\begin{tabular}{|l|c|c|c|c|c|c|c|c|c|}
\hline \multirow{2}{*}{ Regions } & \multicolumn{9}{|c|}{ Total value } \\
\cline { 2 - 12 } & \multicolumn{3}{|c|}{ Innovative activity } & \multicolumn{3}{|c|}{ Investment activity } & \multicolumn{3}{c|}{ Social and economic development } \\
\cline { 2 - 11 } & 2011 & 2012 & 2013 & 2011 & 2012 & 2013 & 2011 & 2012 & 2013 \\
\hline Altai Krai & 59 & 59 & 59 & 53 & 69 & 68 & 79 & 75 & 54 \\
\hline Irkutsk Region & 68 & 62 & 61 & 45 & 43 & 53 & 63 & 61 & 50 \\
\hline Kaluga Region & 59 & 56 & 59 & 37 & 37 & 33 & 52 & 47 & 24 \\
\hline Krasnoyarsk Krai & 47 & 37 & 36 & 40 & 31 & 28 & 39 & 37 & 30 \\
\hline Lipetsk Region & 40 & 35 & 48 & 44 & 48 & 38 & 43 & 46 & 21 \\
\hline Novosibirsk Region & 42 & 43 & 43 & 47 & 46 & 45 & 43 & 45 & 29 \\
\hline
\end{tabular}




\begin{tabular}{|l|c|c|c|c|c|c|c|c|c|}
\hline Perm Krai & 24 & 21 & 28 & 60 & 54 & 57 & 46 & 47 & 34 \\
\hline Republic of Bashkortostan & 35 & 29 & 32 & 41 & 49 & 41 & 37 & 36 & 24 \\
\hline Republic of Mordovia & 40 & 43 & 47 & 71 & 77 & 71 & 73 & 74 & 48 \\
\hline Republic of Tatarstan & 12 & 9 & 11 & 31 & 28 & 27 & 15 & 15 & 13 \\
\hline Samara Region & 25 & 33 & 25 & 49 & 40 & 34 & 27 & 24 & 14 \\
\hline Tomsk Region & 56 & 46 & 57 & 42 & 44 & 47 & 58 & 61 & 45 \\
\hline Tyumen Region & 30 & 34 & 45 & 31 & 29 & 27 & 15 & 14 & 9 \\
\hline Ulyanovsk Region & 63 & 67 & 65 & 66 & 66 & 64 & 67 & 65 & 40 \\
\hline Kemerovo Region & 72 & 62 & 75 & 55 & 49 & 52 & 55 & 59 & 44 \\
\hline
\end{tabular}

Source: Made up by the authors on the basis of data from Rosstat (2011-2013)

On the basis of calculated data we can point out the regions which have shown a number of leading figures. For instance, the best results in innovative activity (in descending order) were shown by: Republic of Tatarstan, Perm Krai, Samara Region and Tyumen Region; in investment activity: Republic of Tatarstan, Tyumen Region, Kaluga Region and Krasnoyarsk Krai; and, finally, the leaders in social and economic development are Tyumen Region, Republic of Tatarstan, Samara Region and Republic of Bashkortostan.

In order to study a dependence of the regions' innovative and investment activity indicators let us draw a matrix of paired correlation coefficients (Table 6). One of the main indicators of the regions' innovative activity is a volume of innovatory production, works and services. In our research we attempt to find out a dependence of volume of innovatory production, works, services (Y) on indicators of investment activity (X1-X6). We use data of 2013.

Table 6: Matrix of paired correlation coefficients for regions' innovative and investment activity

\begin{tabular}{|c|c|c|c|c|c|c|c|}
\hline & $Y$ & $\mathrm{X} 1$ & $\mathrm{X} 2$ & X3 & $X 4$ & $x 5$ & $X 6$ \\
\hline$Y$ & 1 & & & & & & \\
\hline $\mathrm{X} 1$ & 0,989418 & 1 & & & & & \\
\hline $\mathrm{X} 2$ & $-0,03573$ & 0,071316 & 1 & & & & \\
\hline $\mathrm{X3}$ & $-0,04744$ & $-0,0678$ & 0,310366 & 1 & & & \\
\hline$X 4$ & 0,024928 & 0,084281 & 0,112746 & $-0,23314$ & 1 & & \\
\hline$\times 5$ & 0,992688 & 0,998153 & 0,024895 & $-0,09663$ & 0,082048 & 1 & \\
\hline $\mathrm{X} 6$ & 0,703352 & 0,735273 & 0,307153 & $-0,05458$ & 0,006749 & 0,732261 & 1 \\
\hline
\end{tabular}

Source: Made up by the authors

Let us do a statistical evaluation of the calculations. With a set significance level being 0,05 and a number of degrees of freedom being 14 the critical correlation value equals 0,497 . Therefore, we can say that there is a correlation between a factor $Y$ and factors $X 1, X 5$ and $X 6$ with a probability of 95\%. The analysis of the paired correlation coefficients matrix shows that a dependent variable $Y$ (Volume of innovatory production, works, services, mln. RUR) has a strong connection with a variable X1 (Fixed capital investments, mIn. RUR), variable X5 (Inflows of foreign direct investments in the economy of Russia, mln.dol.) and variable X6 (Accumulated foreign direct investments, mln.dol.). At the same time the factors $X 1, X 5$ and $X 6$ have strong connections with each other which says about their multicollinearity.

In a similar way we investigate the influence of the investment activity indicators on the other indicators of innovative activity. As a result we get the same dependence between the variables. The only exception is an indicator of Innovative activity of organizations (Share of organizations implementing innovations in total number of organizations) which does not correlate with investment activity indicators.

Thus, the obtained results have demonstrated that only a number of chosen indicators influences innovative activity of the regions.

We assume that attraction of investment resources has a favorable effect on general social and economic state of a region. Table 7 contains the results of a correlation analysis for the Gross regional product per capita indicator $(Y)$ and investment activity indicators (X1-X6). 
Table 7: Matrix of paired correlation coefficients for regions' social and economic development and investment activity

\begin{tabular}{|c|c|c|c|c|c|c|c|}
\hline & $Y$ & $X 1$ & $X 2$ & $X 3$ & $X 4$ & $X 5$ & $X 6$ \\
\hline$Y$ & $\mathbf{1}$ & & & & & & \\
\hline$X 1$ & $\mathbf{0 , 1 0 3 3 2 6}$ & 1 & & & & & \\
\hline$X 2$ & $\mathbf{0 , 9 8 1 8 4 6}$ & 0,066178 & 1 & & & & \\
\hline$X 3$ & $\mathbf{0 , 2 6 7 7 9 2}$ & $-0,09955$ & 0,200899 & 1 & & & \\
\hline$X 4$ & $\mathbf{0 , 1 7 4 6 2 4}$ & 0,06668 & 0,261148 & $-0,28034$ & 1 & & \\
\hline$X 5$ & $\mathbf{0 , 0 6 9 2 5 3}$ & 0,998413 & 0,033076 & $-0,11778$ & 0,070129 & 1 & \\
\hline$X 6$ & $\mathbf{0 , 0 3 1 0 3 1}$ & 0,993767 & $-0,00321$ & $-0,11484$ & 0,052102 & 0,995913 & 1 \\
\hline
\end{tabular}

Source: Made up by the authors

As we can see in the Table 7, the indicators $Y$ and $X 2$ have a strong correlation with a probability of 95\%. In other words, Gross regional product per capita is closely connected with Fixed capital investments per capita. Such connection explains the importance of investments into priority areas. Fixed capital investments occupy a great share in GRP of the majority of the regions considered.

Revealing correlations between the other indicators of regional social and economic development and their investment activity have shown that Fixed capital investments per capita has a strong connection with the other socialeconomic indicators except for the Average annual level of unemployed (no correlation in that case). Along with that the indicator of Graduates from higher educational institutions has demonstrated a strong correlation with Fixed capital investments and Fixed capital investments per capita.

Further literature review helped point out another approach to the evaluation of regions innovative activity (Kotsubinskiy et al., 2014). According to this new approach there are two directions for the analysis of innovative activity and two groups of correspondent indicators: the ones which characterize the use of resources (production assets, human and financial resources) and the ones which describe the results of innovative activity (innovative products, influence on operation results). This methodology serves as a basis for the modern form of Rosstat statistical reporting called "\#4 Innovation". When used in respect of a region the first group helps evaluate its innovative potential, whilst the second group analyses how efficient are the investments are.

At the next stage of research on the basis of the approach mentioned above we have developed an evaluation procedure in which we have included the following indicators:

Indicators characterizing resources:

I. Production assets

1. Fixed capital investments, mln. RUR

2. Fixed capital investments per capita (at actual prices), RUR

3. Fixed assets depreciation rate (end of the year), \%

4. Use of advanced production technologies, unit

II. Human resources

1. Number of researchers and engineering and technical workers engaged in R\&D, person

2. Expenditures per 1 worker engaged in R\&D, RUR

3. Number of researchers with an academic degree, person

III. Financial resources

1. Share of gross domestic expenditure on R\&D in GDP, \%

2. Expenses of organizations on technological innovations, mln. RUR

Share of expenditure on technological innovations in gross volume of production, works, services, $\%$

Indicators characterizing results of innovative activity:

I. Indicators of innovative activity

1. Volume of innovatory production, works, services, mln. RUR

2. Share of innovatory production, works, services in gross volume of production, works, services, $\%$

3. Trade of technologies with foreign countries by fields of agreements, $\mathrm{mln}$. dol.

4. Number of issued patents on inventions and useful models, unit

5. Innovative activity of organizations (Share of organizations implementing innovations in total number of organizations), \%

II. Indicators of social-economic development of a region 
1. Gross regional product per capita, RUR

2. Average per capita money income (monthly), RUR

3. Average annual level of unemployed, $\%$

4. Retail trade turnover per capita, RUR

5. Dwellings put in place per 1000 persons, sq.m.

6. Graduates of higher educational institutions, thou. persons

Following the algorithm of the previous calculations we define the place of each region, among the other regions, taken into consideration. The total value for each of the regions is presented in the Table 8.

Table 8: Ranking of regions on the basis of indicators of resources and results of innovative activity

\begin{tabular}{|c|c|c|c|c|c|c|c|c|c|c|c|c|c|c|c|}
\hline \multirow{3}{*}{ Regions } & \multicolumn{9}{|c|}{ Indicators characterizing resources } & \multicolumn{6}{|c|}{$\begin{array}{l}\text { Indicators characterizing results of innovative } \\
\text { activity }\end{array}$} \\
\hline & \multicolumn{3}{|c|}{$\begin{array}{l}\text { Production } \\
\text { assets }\end{array}$} & \multicolumn{3}{|c|}{$\begin{array}{c}\text { Human } \\
\text { resources }\end{array}$} & \multicolumn{3}{|c|}{$\begin{array}{l}\text { Financial } \\
\text { resources }\end{array}$} & \multicolumn{3}{|c|}{ Innovative activity } & \multicolumn{3}{|c|}{$\begin{array}{c}\text { Social-economic } \\
\text { development }\end{array}$} \\
\hline & 궁 & ঙ্ণ & $\stackrel{m}{\stackrel{m}{\sim}}$ & 귱 & ్ㅠㅇ & $\stackrel{m}{\ddot{N}}$ & 궁 & ్ํㅇ & $\stackrel{m}{\check{N}}$ & 궁 & ్ํํ & $\stackrel{m}{\sim}$ & 궁 & 궁 & $\stackrel{m}{\stackrel{m}{\sigma}}$ \\
\hline Altai Krai & 49 & 50 & 46 & 18 & 27 & 34 & 26 & 33 & 39 & 42 & 42 & 42 & 79 & 75 & 54 \\
\hline Irkutsk Region & 32 & 33 & 38 & 14 & 18 & 18 & 22 & 28 & 24 & 56 & 52 & 53 & 63 & 61 & 50 \\
\hline Kaluga Region & 30 & 30 & 30 & 4 & 11 & 15 & 13 & 22 & 18 & 51 & 44 & 52 & 52 & 47 & 24 \\
\hline Krasnoyarsk Krai & 22 & 17 & 17 & 11 & 19 & 23 & 7 & 10 & 7 & 46 & 35 & 35 & 39 & 37 & 30 \\
\hline Lipetsk Region & 35 & 39 & 31 & 15 & 29 & 44 & 17 & 24 & 32 & 34 & 24 & 39 & 43 & 46 & 21 \\
\hline Novosibirsk Region & 29 & 31 & 32 & 5 & 6 & 8 & 11 & 20 & 23 & 33 & 31 & 30 & 43 & 45 & 29 \\
\hline Perm Krai & 39 & 38 & 36 & 5 & 15 & 17 & 12 & 15 & 13 & 19 & 18 & 22 & 46 & 47 & 34 \\
\hline Republic of Bashkortostan & 27 & 30 & 29 & 7 & 12 & 23 & 18 & 26 & 27 & 31 & 28 & 30 & 37 & 36 & 24 \\
\hline Republic of Mordovia & 42 & 42 & 44 & 14 & 29 & 43 & 21 & 29 & 33 & 28 & 26 & 28 & 73 & 74 & 48 \\
\hline Republic of Tatarstan & 19 & 23 & 21 & 3 & 6 & 18 & 6 & 8 & 10 & 11 & 7 & 7 & 15 & 15 & 13 \\
\hline Samara Region & 27 & 28 & 26 & 2 & 13 & 21 & 7 & 11 & 5 & 21 & 23 & 23 & 27 & 24 & 14 \\
\hline Tomsk Region & 34 & 33 & 37 & 8 & 10 & 9 & 20 & 28 & 24 & 42 & 35 & 44 & 58 & 61 & 45 \\
\hline Tyumen Region & 17 & 16 & 17 & 9 & 15 & 21 & 12 & 20 & 22 & 37 & 45 & 55 & 15 & 14 & 9 \\
\hline Ulyanovsk Region & 45 & 45 & 46 & 8 & 21 & 31 & 22 & 33 & 33 & 38 & 44 & 43 & 67 & 65 & 40 \\
\hline Kemerovo Region & 30 & 25 & 30 & 18 & 30 & 35 & 26 & 27 & 36 & 63 & 62 & 68 & 55 & 59 & 44 \\
\hline
\end{tabular}

Source: Made up by the authors on the basis of data from Rosstat (2011-2013)

The obtained results have demonstrated that current approach makes it more difficult to compare regions because of the greater number of indicators. In this case, Tyumen region leads in the use of production assets and social and economic development, Novosibirsk region has the best results in the use of human resources, and, finally, the Republic of Tatarstan gains a leading position in the use of financial resources and innovative activity.

Correlation analysis of the first group of indicators and the indicators of innovative activity from the second group revealed the following. The Volume of innovatory production, works, services, Trade of technologies with foreign countries and Number of issued patents correlate with Fixed capital investments, Use of advanced production technologies, Number of researchers and engineering and technical workers engaged in R\&D, Number of researchers with an academic degree, Share of gross domestic expenditure on R\&D in GDP and Share of expenditure on technological innovations.

Correlation analysis of the first group of indicators and the indicators of social and economic development from the second group showed the following results. Fixed capital investments per capita correlate with Gross regional product per capita and Average per capita money income. At the same time Graduates of higher educational institutions correlate with Fixed capital investments, Use of advanced production technologies, Number of researchers and engineering and technical workers engaged in R\&D, Number of researchers with an academic degree, Share of gross domestic expenditure on R\&D in GDP and Share of expenditure on technological innovations.

\section{Conclusion}

The analysis of the influence of regions innovative and investment activity on their social-economic development allows to 
make the following conclusions. Firstly, taking into account a long-term experience of cluster-based programs implementation it is required to use the best international models of innovative territorial clusters' formation considering the Russian specificities. Innovative and investment activity of the Russian regions is the main driver of their economic growth and social well-being. Secondly, today Russia aims to use advantages of a cluster approach in solving problems of modernization and innovative development of regions. There has been a process of adaptation of a "cluster policy" term to the Russian conditions and specific features of public authorities, science, education, business and society. Thirdly, considering a poor development of market institutions, a key role in the creation of innovative territorial clusters being factors of competitive ability growth belongs to government. In this respect, it is important to work out a conceptual and methodological base and a regulatory framework for cluster policy at the federal level and create favorable conditions by means of public-private partnership and establishment of specific financial institutions. Fourthly, implementation of cluster policy implies coordination of actions of federal state government bodies, executive authorities of the Russian federal subjects, local governments, business and scientific and educational centers. The use of state development institutions' resources should become a significant mechanism for cluster investments projects' financing. Finally, one of the conditions needed for successful innovative development is a presence of a developed innovative infrastructure. In this regard, it is necessary to accelerate formation of new networks of technology parks and increase operating efficiency of existing technology parks. Taking part in such projects will allow Russia to occupy a rightful place in the world economic system.

\section{References}

Akaev, A., Korotaev, A., Malkov, S. (2014). World Dynamics: Patterns, Tendencies, Perspectives (p. 488). Moscow: KRASAND

Antonietti, R., Bronzini, R., \& Cainelli, G. (2015). Inward Greenfield FDI and Innovation. Economia e Politica Industriale, Vol. 42, Iss. 1, pp. 93-116

Association of Innovative Regions of Russia, (2014), Ranking of the Russian Innovative Regions, 2014. [Online] Available: http://www.iregions.org/reyting_innovations_regions.pdf (February 28, 2015)

Driffield, N., Love, J., \& Menghinello, S. (2010). The Multinational Enterprise as a Source of International Knowledge Flows: Direct Evidence from Italy. Journal of International Business Studies, Vol.41, pp. 350-359

Driffield, N., Love, J., Lancheros, S., \& Temouri, Y., (2013), How Attractive is the UK for Future Manufacturing Foreign Direct Investment? [Online] Available: https://research.aston.ac.uk/portal/en/researchoutput/how-attractive-is-the-uk-for-future-manu facturing-foreign-direct-investment\%283618b151-a881-4cfc-8036-bf4bf0a7f9c7\%29 /export.html (February 28, 2015)

Expert RA Rating Agency, (2014), Ranking of the Russian regions' Investment Attractiveness [Online] Available: http://www.raexpert.ru/ ratings /regions/2014 (March 1, 2015)

Giblin, M., (2008), Inward Foreign Investment and the Clustering Process: the Case of the Medical Technology Sector in Ireland. [Online] Available: http://www.nuigalway.ie/cisc/documents/ 00029ciscwp.pdf (March 1, 2015)

Government of the Russian Federation, (2014), On Appropriations for Pilot Innovative Territorial Clusters' Development Programs. [Online] Available: http://government.ru/dep_news/ 14121/ (February 25, 2015)

Hart, D.A., (2001), Innovation Clusters: Key Concepts. [Online] Available: http://www.reading.ac.uk/LM/LM/fulltxt/0600.pdf (February 28, 2015)

Jones, J., Wren, C., (2008), Foreign Direct Investment and Prospects for the Northern Region. [Online] Available: http://www. spatialeconomics.ac.uk/textonly/SERC/ publications/download/sercdp0004.pdf (March 1, 2015)

Kotsubinskiy, V., Yeremkin V. (2014). Measuring a Level of Innovative Development: International Practice and Russian Experience (p.194). Moscow: Delo

Lipsey, P., \& Sjöholm, F., (2004), The Impact of Inward FDI on Host Countries: Why Such Different Answers? [Online] Available: http://swopec.hhs.se/eijswp/papers/ eijswp0192.pdf (February 25, 2015)

Menghinello, S., De Propris, L., \& Driffield N. (2010). Industrial Districts, Inward Foreign Investment and Regional Development. Journal of Economic Geography, Vol. 10, Iss. 4, pp. 539-558

Ministry of Economic Development of the Russian Federation, (2008), Concept of Long-term Social and Economic Development of the Russian Federation until 2020. [Online] Available: http://economy.gov.ru/minec/activity/sections/strategicplanning/concept/ doc20081117_01 (February 25, 2015)

Ministry of Economic Development of the Russian Federation, (2012), Project of the List of ITC Pilot Development Programs. [Online] Available: http://economy.gov.ru/minec/ activity/sections/strategicplanning/concept/ doc20081117_01 (February 25, 2015)

Phelps, N. (2008). Cluster or Capture? Manufacturing Foreign Direct Investment, External Economies and Agglomeration. Regional Studies, Vol. 42, Iss. 4, pp. 457-473

Rosstat, (2012), Russian Regions. Social-economic Indicators. Statistical Yearbook, 2012. [Online] Available: http://www.gks.ru/bgd/ regl/B12_14p/Main.htm (March 2, 2015)

Rosstat, (2013), Russian Regions. Social-economic Indicators. Statistical Yearbook, 2013. [Online] Available: http://www.gks.ru/bgd/regl/ B13_14p/Main.htm (March 2, 2015)

Rosstat, (2014), Russian Regions. Social-economic Indicators. Statistical Yearbook, 2014. [Online] Available: http://www.gks.ru/bgd/ 
regl/b14_14p/Main.htm (March 2, 2015)

Russian Cluster Observatory, (2013), Pilot Innovative Territorial Clusters in the Russian Federation. [Online] Available: http://cluster.hse. ru/doc/Пилотные инновационные территориальные кластеры в РФ.pdf (February 24, 2015)

Russian Cluster Observatory, (2013), Territorial Clusters. News Digest. [Online] Available: http://cluster.hse.ru/doc/ Дайджест новостей Территориальные кластеры 12.2013.pdf (February 26, 2015)

Tyuleneva, N. (2013). New Configuration of Russian Regional Economics Based on Cluster Development Programs. ERIEP [Online] Available: http://revel.unice.fr/eriep/index. html?id=3482 (March 10, 2015)

Tyuleneva, N. (2013). The Future of the Russian Regions: "Raw-exports Role" or Innovative Territorial Cluster? Bulletin of Peoples' Friendship University of Russia, Series: Economics, Iss. 5, pp. 169-179 